2016 - Volume: 5 Number: 1

Page: $31-35$

DOI : $10.18036 /$ btdc. 13390

Received: 28 February 2016 Revised: 29 March 2016 Accepted: 30 March 2016

\title{
VOLATILE COMPOUNDS OF COFFEA ARABICA L. GREEN AND ROASTED BEANS *
}

\author{
İlham ERÖZ POYRAZ ${ }^{1, * *}$, Nilgün ÖZTÜRK ${ }^{2}$, H. Tuba KIYAN ${ }^{2}$, Betül DEMİRCİ ${ }^{2}$ \\ ${ }^{1}$ Department of Pharmaceutical Botany, Faculty of Pharmacy, Anadolu University, 26470 Eskişehir, Turkey \\ ${ }^{2}$ Department of Pharmacognosy, Faculty of Pharmacy, Anadolu University, 26470 Eskişehir, Turkey
}

\begin{abstract}
Volatile compounds of green and roasted beans of Coffea arabica L. (Rubiaceae) were investigated by this study. Volatile compounds were trapped with Headspace Solid-Phase Microextraction (HS-SPME) technique and analyzed by Gas Chromatography-Mass Spectrometry (GC/MS). The main components of the green coffee were identified as isoamylalcohol $(10.4 \%)$, hexanal $(10.4 \%)$ and hexacosane $(8.2 \%)$ while furfurylalcohol $(13.6 \%)$, furfurylacetate $(10.7 \%)$ and 5-methyl furfural $(9.27 \%)$ were identified as the main components of the roasted coffee. In conclusion, using HP-SPME-GC-MS, it was possible to quantify different volatile compouns like as alcohols, aldehydes, ketones, pyrazines, pyridines, and furans in green and roasted coffee beans which belong to different chemical classes.
\end{abstract}

Keywords: Coffea arabica L., Green coffee, Roasted coffee, Volatile compounds

\section{COFFEA ARABICA L.'NIN YEŞİL VE KAVRULMUŞ ÇEKIRDEKLERININ UÇUCU BİLEŞENLERI}

\begin{abstract}
ÖZET
Bu çalışmada Coffea arabica L. (Rubiaceae)'nın yeşil ve kavrulmuş çekirdeklerinin uçucu bileşikleri incelenmiştir. Uçucu bileşenler, Headspace Katı Faz Mikroekstraksiyon (HS-SPME) tekniği ile elde edilmiş ve Gaz Kromatografisi-Kütle Spektrometresi (GC/MS) ile analiz edilmiştir. Yeşil kahve çekirdeklerinin ana bileşenleri izoamilalkol (\% 10.4), hekzanal (\% 10.4) ve hekzakosan $(\% 8.2)$ iken, kavrulmuş çekirdeklerin ana bileșenleri förfurilalkol $(\% 13.6)$, förfurilasetat $(\% 10.7)$ ve 5metil förfural (\% 9.27) olarak belirlenmiştir. Sonuç olarak, HS-SPME-GC-MS kullanılarak yeşil ve kavrulmuş kahve çekirdeklerinde alkol, aldehit, keton, pirazin, piridin ve furan gibi değişik kimyasal gruplara ait farklı uçucu bileşenlerin belirlenmesi mümkün olmuştur." şeklinde olmalıdır.
\end{abstract}

Anahtar Kelimeler: Coffea arabica L., Yeşil kahve, Kavrulmuş kahve, Uçucu bileşikler

\section{INTRODUCTION}

Coffee is one of the most popular beverages around the world, constituting a significant portion of daily beverage intake in many Western countries. With the advancement of the research on antioxidants and health, coffee has been recognized as a rich source of dietary antioxidants with potential to improve health [1]. Green coffee beans are a major source of chlorogenic acid in nature and consumption of them produced antihypertensive effect, improvement in human vasoreactivity, inhibitory effect on fat accumulation and body weight in mice and humans [2]. The roasting process of green coffee beans reduces amounts of some chlorogenic acid isomers [3,4]. The basic chemical composition of green coffee depends primarily on genetic aspects, especially species, and on physiologic aspects such as degree of maturation. The poor volatile fraction of unroasted coffee seeds gives them a weak but characteristic aroma. Approximately 100 different volatile compounds have been identified in green coffee seeds. The variety and concentrations of volatile compounds in roasted coffee depend on the composition of nonvolatile compounds in the raw seeds and on roasting conditions. Therefore, the factors such as genetics, soil,

\footnotetext{
* This study was presented as a poster on 45th ISEO International Symposium on Essential Oils, 7-10 September 2014, Istanbul.

**Corresponding Author: ieroz@anadolu.edu.tr
} 
agricultural practices, climate, and degree of maturation influence the final composition of the volatile fraction of roasted coffee. More than 950 compounds have been identified after roasting in different types of coffee, depending on their origin, degree of roasting, and analytical methods used [5].

Determination of the HS-SPME volatile profile of the green and roasted beans of Coffea arabica L. obtained commercially was aimed in this study.

\section{MATERIAL and METHODS}

Coffea arabica L. (Rubiaceae) green and roasted beans were obtained from a local market in Eskişehir, Turkey in 2014 (Temiz-I่̧ş Kurukahveci, Eskişehir).

\subsection{Headspace-SPME}

The manual SPME device (Supelco, Bellafonte, PA, USA) with a fiber precoated of a $65 \mu \mathrm{m}$ thick layer of polydimethylsiloxane/divinylbenzene (PDMS/DVB-blue) was used for extraction of the volatiles. The vial containing the sample was sealed with parafilm. The fiber was pushed through the film layer for exposure to the headspace of the coffee beans for $15 \mathrm{~min}$ at $50^{\circ} \mathrm{C}$. The fiber was then inserted immediately into the injection port of the GC/MS for desorption of the adsorbed volatile compounds for analysis.

\subsection{GC/MS Analysis}

The GC/MS analysis was carried out with an Agilent 5975 GC-MSD system. Innowax FSC column (60 $\mathrm{m} \times 0.25 \mathrm{~mm}, 0.25 \mathrm{~mm}$ film thickness $)$ was used with helium as carrier gas $(0.8 \mathrm{~mL} / \mathrm{min})$. GC oven temperature was kept at $60^{\circ} \mathrm{C}$ for $10 \mathrm{~min}$ and programmed to $220^{\circ} \mathrm{C}$ at a rate of $4^{\circ} \mathrm{C} / \mathrm{min}$, and kept constant at $220^{\circ} \mathrm{C}$ for $10 \mathrm{~min}$ and then programmed to $240^{\circ} \mathrm{C}$ at a rate of $1{ }^{\circ} \mathrm{C} / \mathrm{min}$. The injector temperature was set at $250^{\circ} \mathrm{C}$. Mass spectra were recorded at $70 \mathrm{eV}$. Mass range was from $\mathrm{m} / \mathrm{z} 35$ to 450 . Identification of the volatile components were carried out by comparison of their relative retention times with those of authentic samples or by comparison of their relative retention index (RRI) to series of $n$ alkanes. Computer matching against commercial (Wiley GC/MS Library, MassFinder3 Library) [6, 7] and in-house "Başer Library of Essential Oil Constituents" built up by genuine compounds and components of known oils, as well as MS literature data [8,9], was used for the identification.

\section{RESULTS}

The chromatogram of the green/roasted coffee beans is represented in Figure 1. This study aimed the determination of the HS-SPME volatile profile of green and roasted beans of Coffea arabica L. The main components for green coffee were identified as hexanal (10.4\%), isoamylalcohol $(10.4 \%)$ and hexacosane $(8.2 \%)$, while furfurylalcohol (13.6\%), furfurylacetate $(10.7 \%)$ and 5-methyl furfural $(9.3 \%)$ were identified as the main components of the roasted coffee (Table 1). 
Eröz Poyraz et al. / Anadolu Univ. J. of Sci. and Technology-C-Life. Sci. and Biotech. 5 (1) - 2016

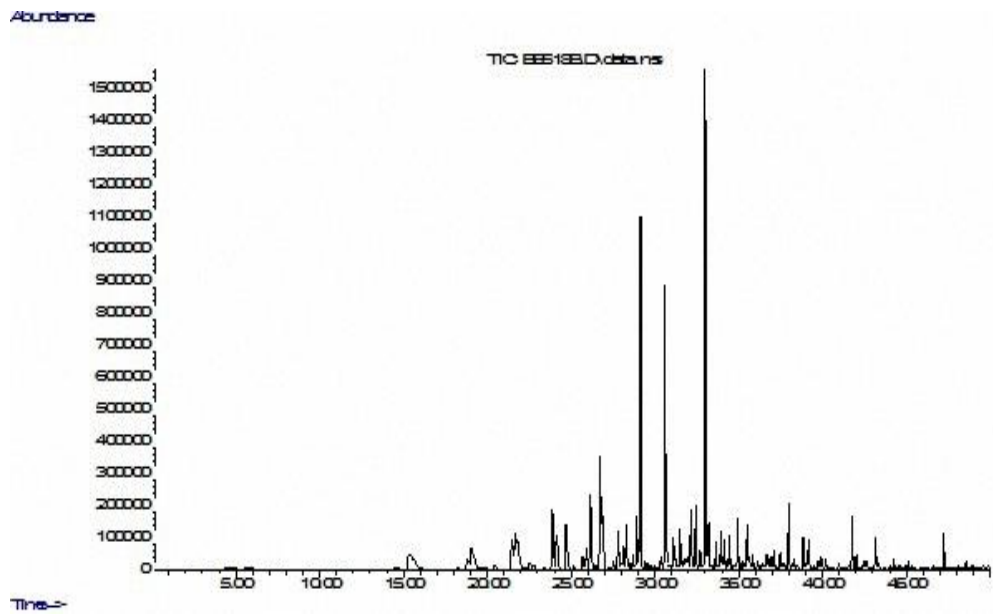

Figure 1. The HS-SPME chromatogram of roasted coffee beans.

Table 1. Volatile compounds of green coffee beans and roasted coffee beans obtained by HS-SPME-GC-MS.

\begin{tabular}{|c|c|c|c|c|}
\hline Peak No & RRI* & Volatile Compounds & Green Coffee Beans (\%) & Roasted Coffee Beans (\%) \\
\hline 1 & 1093 & Hexanal & 10.4 & - \\
\hline 2 & 1187 & Pyridine & - & 3.1 \\
\hline 3 & 1213 & Isoamylalcohol & 10.4 & - \\
\hline 4 & 1259 & 1-Pentanol & 2.3 & - \\
\hline 5 & 1274 & Methylpyrazine & - & 2.1 \\
\hline 6 & 1280 & p-Cymene & 1.3 & - \\
\hline 7 & 1322 & 2-Heptanol & 3.6 & - \\
\hline 8 & 1332 & 2,5-Dimethylpyrazine & - & 1.8 \\
\hline 9 & 1335 & (E)-2-Heptenal & 1.2 & - \\
\hline 10 & 1337 & 2,6-Dimethylpyrazine & - & 2.1 \\
\hline 11 & 1343 & 2-Ethylpyrazine & - & 1.6 \\
\hline 12 & 1360 & 1-Hexanol & 2.8 & - \\
\hline 13 & 1391 & 2-Ethyl-6-methylpyrazine & - & 3.4 \\
\hline 14 & 1395 & 2-Ethyl-5-methylpyrazine & - & 2.3 \\
\hline 15 & 1400 & Nonanal & 1.5 & - \\
\hline 16 & 1409 & Trimethylpyrazine & - & 2.8 \\
\hline 17 & 1450 & trans-Linalool oxide (Furanoid) & - & 1.0 \\
\hline 18 & 1452 & 1 -Octen-3 ol & 4.1 & - \\
\hline 19 & 1452 & 2-Ethyl-3,5-dimethylpyrazine & - & 3.7 \\
\hline 20 & 1454 & 1-Acetoxy-2-propanone & - & 3.8 \\
\hline 21 & 1479 & Furfural & - & 2.8 \\
\hline 22 & 1506 & Furfurylformate & - & 1.6 \\
\hline 23 & 1516 & 2-Acetyl furan & - & 1.6 \\
\hline 24 & 1541 & Benzaldehyde & 3.8 & - \\
\hline 25 & 1547 & Furfuryl acetate & - & 10.7 \\
\hline 26 & 1553 & Linalool & 3.0 & - \\
\hline 27 & 1586 & 5-Methylfurfural & - & 9.3 \\
\hline 28 & 1638 & 2-Formyl-N-methylpyrrole & - & 1.8 \\
\hline 29 & 1648 & $\gamma$-Butyrolactone & 0.9 & 2.0 \\
\hline 30 & 1671 & Furfurylalcohol & - & 13.6 \\
\hline 31 & 1684 & Isovaleric acid & - & 1.4 \\
\hline 32 & 1845 & $N$-Furfurylpyrrole & - & 1.8 \\
\hline 33 & 1896 & Benzylalcohol & 0.9 & - \\
\hline 34 & 1937 & Phenylethylalcohol & 3.2 & - \\
\hline 35 & 1996 & 2-Acetylpyrrole & - & 1.6 \\
\hline 36 & 2218 & 4-Vinylguaiacol & - & 0.9 \\
\hline 37 & 2300 & Tricosane & 2.5 & - \\
\hline 38 & 2400 & Tetracosane & 5.0 & - \\
\hline 39 & 2500 & Pentacosane & 7.6 & - \\
\hline 40 & 2600 & Hexacosane & 8.2 & - \\
\hline 41 & 2700 & Heptacosane & 7.6 & - \\
\hline 42 & 2800 & Octacosane & 6.8 & - \\
\hline \multirow[t]{2}{*}{43} & 2900 & Nonacosane & 6.3 & - \\
\hline & & TOTAI & 93.4 & 76.8 \\
\hline
\end{tabular}

*RRI: Relative retention indices calculated against $n$-alkane \% calculated from TIC (Total Ion Chromatogram) data. 


\section{DISCUSSION}

It was reported in IARC Monograph the most abundant volatile compounds are alcohols, esters, hydrocarbons and aldehydes in green coffee beans. Ketones, pyrazines, furans and sulfur compounds have also been identified [10]. The maturation stage of the coffee fruits is important for the volatile composition of green coffee. The poor volatile fraction of unroasted coffee seeds gives them a weak but characteristic aroma. Approximately 100 different volatile compounds have been identified in green coffee [5]. In raw coffee, some 200 volatiles have been identified. Some raw coffee volatiles (geosmin, 2,4,6-trichloroanisol/-phenol, 4-heptenal etc.) were identified as characteristic for defects, which are externally caused, maybe by over-fermentation during processing or by insect attacks or immaturity of beans [11]. In another research, the major volatile compounds in green beans were determined as aldehydes (hexanal and benzaldehyde) and alkanes (tetradecane and cyclopentasiloxane, decamethyl-, cyclohexane, 1-methyl-4-(1-methylethenyl)-, cis- and cyclotetrasiloxane, octamethyl-), whereas the major volatile compounds in roasted beans were determined furans, pyrazines, and pyridines [12]. Along with green coffee beans HS-SPME results, (E)-2-heptenal and some alkanes (tricosane, tetracosane etc.) were identified.

The variety and concentrations of volatile compounds in roasted coffee depend on the composition of non-volatile compounds in the raw seeds and on roasting conditions. Therefore, the factors such as genetics, soil, agricultural practices, climate, and degree of maturation influence the final composition of the volatile fraction of roasted coffee. More than 950 compounds have been identified after roasting in different types of coffee, depending on their origin, degree of roasting, and analytical methods used. The classes of volatile compounds typically found in roasted coffee are furans and pyrans, pyrazines, pyrroles, ketones and phenols, hydrocarbons, alcohols, aldehydes, acids and anhydrides, esters, lactones, thiophenes, oxazoles, thiazoles, pyridines, amines, and various sulfur and nitrogen compounds. The formation of volatile compounds depends on the stability of their precursors and location within the seed. In addition, different volatile profiles have been observed in coffee samples roasted under different conditions to achieve the same roasting degree. Compounds that may be affected by roasting conditions include pyridine, 2-methylpyrazin, furfural, furfuryl formate, 2furanomethanol acetate, 5-methyl-furancarbaldehyde, 1-(2-furanylmethyl)-1H-pyrrol, 1-(1H-pyrrol-2yl)-ethanone, 2-methoxyphenol, and 4-ethyl-2-metoxyphenol. Roasted coffee beans contain odorants as 3-isobutyl-2-methoxypyrazine, 2-methoxy-3-isopropylpyrazine, 2-methoxy-3,5-dimethylpyrazine, 4-vinylguaiacol nearly same concentration or much more than green coffee beans (Oestreich-Janzen 2010). Depend on HS-SPME results of roasted coffee beans, there were determined 2-ethyl-5methylpyrazine, 2-ethyl-6-methylpyrazine, 2,5-dimethylpyrazine, 2,6-dimethylpyrazine, and 4vinylguaiacol.

\section{CONCLUSION}

Using HS-SPME-GC-MS, it was able to quantify different volatile compounds as alcohols, aldehydes, ketones, pyrazines, pyridines, and furans in green and roasted coffee beans belonging to different chemical classes but specific for green or roasted coffee beans obtained commercially. The major volatile contents showed that the percentages of hexanal, p-cymene, (E)-2-heptenal, nonanal, benzaldehyde, linalool and alcohols (isoamylalcohol, 1-pentanol, 2-heptanol etc.) and tri- to nonacosanes in green coffee beans, whereas those of pyridine, methylpyrazine and dimethylpyrazine derivatives, trimethylpyrazine, 1-acetoxy-2-propanone, furfuryl and pyrrole derivatives, alcohols (benzylalcohol, phenylethylalcohol) and isovaleric acid were in roasted beans. 
Eröz Poyraz et al. / Anadolu Univ. J. of Sci. and Technology-C-Life. Sci. and Biotech. 5 (1) - 2016

\section{REFERENCES}

[1] Chu YF, Brown PH, Lyle BJ, Chen Y, Black RM, Williams CE, Lin YC, Hsu CM, Cheng IH. Roasted coffees high in lipophilic antioxidants and chlorogenic acid lactones are more neuroprotective than green coffees. J Agric Food Chem 2009; 57: 9801-9808. doi: 10.1021/jf902095z

[2] Farah A, Monteiro M, Donangelo CM, Lafay S. Chlorogenic acids from green coffee extract are highly bioavailable in humans. J Nutr 2008; 138: 2309-2315. doi: 10.3945/jn.108.095554

[3] Moon JK, Yoo HS, Takayuki S. Role of roasting conditions in the level of chlorogenic acid content in coffee beans: correlation with coffee acidity. J Agric Food Chem 2009; 57: 5365-5369. doi:10.1021/jf900012b

[4] Tfouni SAV, Serrate CS, Carreiro LB, Camargo MCR, Teles CRA, Cipolli KMVAB, Furlani RPZ. Effect of roasting on chlorogenic acids, caffeine and polycyclic aromatic hydrocarbons levels in two Coffea cultivars: Coffea arabica cv. Catuaí Amarelo IAC-62 and Coffea canephora cv. Apoatã IAC2258 Int J Food Sci Tech 2012; 47: 406-415.

[5] Farah A. Coffee constituents. In: Chu YF editor. Coffee: Emerging Health Effects and Disease Prevention. First Edition. John Wiley \& Sons, Inc. Published, 2012. pp. 21-58. http://www.ift.org/ /media/Knowledge\%20Center/Publications/Books/Samples/IFTPressBook_Coffee _PreviewChapter.pdf (accessed 08.I.2016).

[6] McLafferty FW, Stauffer DB. The Wiley/NBS Registry of Mass Spectral Data. New York: J Wiley and Sons, 1989.

[7] Koenig WA, Joulain D, Hochmuth DH. Terpenoids and Related Constituents of Essential Oils MassFinder 3. Hamburg, Germany, 2004.

[8] Joulain D, Koenig WA. (1989). The Atlas of Spectra Data of Sesquiterpene Hydrocarbons. EBVerlag, Hamburg.

[9] ESO 2000. The Complete Database of Essential Oils. The Netherlands: Boelens Aroma Chemical Information Service, 1999.

[10] World Health Organization (WHO), International Agency for Research on Cancer. IARC Monographs on the Evaluation of Carcinogenic Risks to Humans, Coffee, Tea, Mate, Methyxanthines and Methylglyoxal. Lion, France: IARCK, 1991; 51: 61-89.

http://monographs.iarc.fr/ENG/Monographs/vol51/mono51.pdf (accessed 11.I.2016)

[11] Oestreich-Janzen S. Chemistry of Coffee. In: Mander L, Liu HW editors. Comprehensive Natural Products II, Vol. 3, Elsevier B.V., 1085-1117, 2010. doi:10.1016/B978-008045382-8.00708-5 2010

[12] Somporn C, Kamtuo A, Theerakulpisut P, Siriamorn S. Effects of roasting degree on radical scavenging activity, phenolics and volatile compound of Arabica coffee beans (Coffea arabica L. cv. Catimor) Int J Food Sci Tech 2011; 46: 2287-2296. doi:10.1111/j.1365-2621.2011.02748.x; 46: 22 